\title{
THE ANALYSIS OF SEMANTIC AND PRAGMATIC CONTEXT IN TOEFL TEST SIMULATION ON LISTENING SECTION
}

\author{
Rakha Setyawan ${ }^{1}$, Triastama Wiraatmaja ${ }^{2}$ \\ English Language Education Department, Faculty of Teacher Training and Education \\ University of Muhammadiyah Malang \\ email: raakhasetyawan@gmail.com
}

\begin{abstract}
Sociolinguistics aspects such as Semantic and Pragmatic affect language user in every situation. Those two contexts even exist in a proficiency test to become the test foundation. This research was conducted to identify the semantic and pragmatic contexts in TOEFL test simulation on the Listening section. The researcher applied a qualitative descriptive approach to this research, and Document Analysis and the researcher as the instrument. The object of this research was TOP NO 1 TOEFL SIMULATION published by FORUM TENTOR INDONESIA. The result reveals that there are several types of semantic and pragmatic context found in the test simulation. The semantic contexts found in 8 questions from the 30 questions analyzed. The types of semantic contexts which were found namely; Meaning, Semantic Feature, and Semantic Roles. Moreover, the semantic type that mostly occurred is Semantic Roles (4 Questions), then followed by Semantic Feature (2 Questions) and Meaning (2 Questions). However, the Pragmatic context quantities are found more than the semantic context. From the 30 analyzed questions, the Pragmatic contexts found are 40 questions, it happens because one test item can have more than one type of pragmatic. Also, the Reference type in Pragmatic occurred in most questions because the narrator on the listening passage uses referencing (nature of Reference) to make the question. The type of pragmatic context found namely; Context, Politeness, Reference, and Speech Act. The type of pragmatic context which is mostly occurred is Reference (25 questions).
\end{abstract}

Keywords :Semantic, Pragmatic, TOEFL test, Listening

\section{Introduction}

Sociolinguistics aspects affect the language user in every context. As a social person, we tend to deliver a communication when we meet someone, it could be about whether, a simple question about how was their day, or rather just single hello (Trudgil, 2000). Language and society cannot be separated as Trudgil (2000) mentioned language is the 'bridge' in making people into relation. There are many communication acts that we used related to its sociolinguistics term, an example of the contexts which mostly we used daily is semantic and pragmatic. Yule (2010) in his book "The Study of Langue" explains the meaning of semantic and pragmatic. Semantic is the recognition of words meaning and pragmatic is recognition of words meaning or speaker meaning in their utterance, thus pragmatic reviews in the study of hidden meaning context. The pragmatic theories also justified before Yule's concept by Leech (1983) he suggests pragmatic is the study of meaning in the situation that happens with systematic pattern and rule to discover particular languages preference in situational meaning. Meanwhile

CELTIC: A Journal of Culture, English Language Teaching, Literature \& Linguistics

PISSN 2356-0401 EISSN 2621-9158

VOLUME 5 NO 22018 
the meaning of semantic according to Yule (2010), "Semantics is the study of the meaning of words, phrases, and sentences. In the semantic analysis, there is always an attempt to focus on what the words conventionally mean, rather than on what a speaker might want the words to mean on a particular occasion".

Derived from the explanation, it proved in learning of the language or when the language applied, we should also consider the existent of semantic and pragmatic. Language users are expected to understand those two in order to fully mastering advanced language use, they should know to find the meaning behind it otherwise the language will not communicative. Jong (2002) states the requirement of language learner to fully achieved pragmatic competent, they should develop the ability to perform speech acts, express and construe non-literal meaning, also bring discourse and politeness function for knowledge related to cultural aspect. It will be the same as semantic in the term of its application as it is easier to comprehend than pragmatic.

When the one has already achieved the aspects, and combine with their language ability we can measure how great they are with language test. The language test is credential accepted to determine language ability as long as the purpose met and choosing appropriate tests (McNamara, 2010). TOEFL is one of standard language proficiency test which its fame increases along with the L2 English learner numbers, through the years this test is determined to score English user ability and to take this test also a must in the certain application.

The researcher in this paper will contribute about analysis of semantic and pragmatic content that inserted as the element of the question, it is in purpose to create authenticity in test, as such the test taker should be listening to native speakers speak in those two situational in real life and so test maker really considered authenticity of response (McNamara, 2010). However, it is different with several previous studies, namely "An investigation into Pragmatic Knowledge in Reading Section of TOLIMO, TOEFL, and IELTS Examinations" and "Pragmatic comprehension of High and Low-Level Language Learners". The significant identical point is they do not mention the basic way how to identify a test item is considered as semantic and pragmatic test. They only focused on how to assess semantic and pragmatic in proficiency test only with the students score as the variables. It is an interesting point and lead researcher concerning to conduct a research in this point of view sociolinguistics aspect in term of semantic and pragmatic sense. In this case the test taker, whether the use of semantic and pragmatic somehow will be confused and feel hardship in the proficiency especially they are not familiar with those aspects. Therefore, the researcher aims to create a new knowledge to introduces the problem solving of theirs confuses, this research could an insight for test taker before going into test. Also, the reason why only TOEFL test other than Proficiency Test i.e. IELT, TOEIC or etc. is being analyzed in this is because of researcher capability on focusing one Proficiency test only. It will be too difficult describe every Proficiency test in a single research with sociolinguistic variable too. Also, TOEFL along with IELT which are the final score of those tests are mostly asked in some requirement. According to global statistics over 2.2 million IELTS test are 
taken every time. The same amount of numbers estimated same with the TOEFL test taker regarding these two tests are the most test that accepted in many countries.

\section{Semantic}

Yule (2010) in his book The Study of Language explains the semantic meaning which is the recognition of words meaning. In more broad meaning, semantic covers a study of words, phrases, and sentence. Katz (1972: 1) states, semantics is a study of meaning in which sentence and other linguistics object express are its concern, not with the arrangement with their syntactic parts or with their pronunciation."Semantic has been a long study. It is believed the semantic term was introduced at the end of the 19th century. Semantics originates by etymology from Greek word semantikos which means 'significant'; semainein means 'to show, signify' or 'indicated by sign'; from sema means 'sign'. There are several semantic content described in Yule (2010) book StudyofLanguage, he categorized the type of semantic in specific based on the situation to select which language into the term meaning, semanticfeatures, semanticroles, lexicalrelation, and collocation

\section{Meaning}

Meaning in semantic categories into two; conceptual meaning and associative meaning. Conceptual meaning is a meaning for describing or explaining by the literal basic diction use of a word. As an example, the English word 'needle' that can create a concept of "thin, sharp, steel object'. However, different with associative meaning, the word "needle' might interpret it with "pain," or "illness," or "blood," or "drugs," or "thread," or "knitting," or "hard to find" (idiom for finding needle in the haystack). These associations can differ from a person to another.

\section{Semantic feature}

Semantic features tend to explain the oddness of semantic. For example the sentence 'The hamburger ate the boy'. By the syntactic structure, those sentences are correct but semantically weird. We can see into the problem hamburger is not capable of 'eating' property like the boy although both of them are the noun. We can make this applicable by trying to identify the feature that any noun supposed to have in order used the ate verb. That feature may be known as "animate being". In here as the example, the animate being is the boy who eats inanimate being which the hamburger is.

\section{Semantic roles}

Semantic rolesexplains the agent or theme, or Instrument and experiencer in a sentence. It can be seen in the word 'they boy kick the ball'. In here the agent is the boy who has an act and the ball as the theme because it is affected by the action. The noun phrases in the sentence describe the roles of entities, such as people and things, involved in the action.It is not necessary to be always a living thing to be the agent, because inanimate object like wind can also become an agent with the example the wind throws the leaf.Instrument and experiencer in the other hand have a different

CELTIC: A Journal of Culture, English Language Teaching, Literature \& Linguistics 
meaning.Something that been used by the agent to do an act is an Instrument, example; the boy cut the paper with the knife and draw with a crayon, those knife and crayon are the instruments. Meanwhile, the experiencer is a noun phrase is used to designate an entity as the person who has a feeling, perception or state.

\section{Lexical relation}

This content explains several things such as synonymy, antonymy, and hyponymy. Synonyms are two or more words with very closely meanings, the example is: almost/nearly, big/large, broad/wide, buy/purchase, and etc. Antonyms are two forms with opposite meanings, the examples are: alive/dead, big/small, fast/slow, and etc. Hyponyms happen when the meaning of one form is included in the meaning of another, the example is animal/dog, dog/poodle, vegetable/carrot, flower/rose, and etc. there is a term such as characteristic instancethat explains about prototype. Penguin and dove are birds but in the term to have close resemble, pigeon and dove have closer resemble than, pigeon to penguin becausethe 'shape' are alike, the feather, or their ability to fly. Homophones are two or more different written forms that have the same pronunciation, example meat/meet, flour/ flower, pail/pale, and etc. Meanwhile, homonyms are one form has two or more unrelated meanings, the example is the bank (of a river) - bank (financial institution) and bat (flying creature) - bat (used in sports). Polysemy is one form, either spoken or written form, having multiple meanings that are all related by extension, example: the word head, use to refer to the object on top of your body, cover on top of a glass of beer, and it can clarifies the person at the top of a company or department, and many other things. Using one of the words to refer to the other is called metonymy, example: king/crown, the President/the White House.

\section{Collocation}

Collocation is a word that seemingly occurred together. For the example, the hammer will say it paired with the nail. Table with a chair and butter elicits bread, needle elicits thread and salt elicits with pepper

\section{Pragmatic}

Pragmatic is a study of 'not shown' meaning of a language(Yule, 2010). Leech (1983) also explains pragmatic is the study of meaning in the situation that occurs in chronological pattern and rule to discover a particular language preference in situational meaning.It also argued by Van Dijk (1977), how to comprehend pragmatic is unique from another linguistics comprehension because it needs contextual information, interlocutor role play statues, the physical setting of the conversation, and types of context that probably has the occurrence of the communicative act. In many ways, pragmatic do a study about 'hidden' meaning, or how we identify what is the meaning even when it is not written or spoken. As same as the content of semantics, Pragmatic also described In Yule (2010) in his book Study of Language, he categorized the content of pragmatic in specific based on the situation to select which language into the term context, reference, speechact, and politeness.

Context

There are different kinds of context; linguisticcontext is the set of other words used in the same phrase or sentence and physicalcontext is to make us know how to interpret

CELTIC: A Journal of Culture, English Language Teaching, Literature \& Linguistics

PISSN 2356-0401 EISSN 2621-9158

VOLUME 5 NO 22018 
the words. Linguisticscontext constitutes the meaning of a word according to its use, in the example of 'head', these two sentences will have different meaning; he was ahead of me in grades and I have to go to head office. The physical context in example if we see a word Restaurant in a building, as obviously, we can assume its place for having meals. In context, there is also Deixis. Deixis means pointing via language. Persondeixis uses to point the things and people; spatialdeixis uses to point a location; temporaldeixis uses to point a time.

Reference

Reference is an act by which a speaker uses a language to enable a listener to identify something. The key process of naming something associated with things to refer people is called inference. As an example, we can make a reference name like Jennifer to my friend but reference is too abroad and we can assume the name Jennifer in the world is only that friend of us. In here there is anaphora and presumption. Anaphora explains the "referring back" as an example a wild kitten run into my kitchen, then that cat spoiled my soup. The kitten changed into cat but did not become a different object. Then, presumption is the speakers assume is true or known by a listener. To be clear, an example of presumption is "Ben, how are your children?" There are two assumptions from the passage at first Ben is a father and already had family second Ben has more than one child. Of course, it was not mentioned in the question but because of the small information we try to assume as much information as we can.

Speech act

Speech act uses to describe an action such as "requesting", "commending", "questioning", or "informing". Direct speech act happens when an interrogative structure is used with the function of question, in example 'can you close the door?'.Indirect speech act happens when we are using syntactic structure associated with the function of a question, but in this case without the function of request, in example 'You forget to shut the door' in a case when somebody just enter the room and let the door open, as such you indirectly order them to close the door.

Politeness

Politeness can be defined as showing awareness and consideration of another person's 'face'. If you say something that represents a threat to another person's selfimage that is called face threatening act (give that book!), meanwhile whenever you say something that lessens the possible threat to another's face it is called face-saving act (could you give me that book?). Negative face is the need to be independent and free from imposition, meanwhile positive faceis the need to be connected. In Yule (2010) "So, a face-saving act that emphasizes a person's negative face will show concern about imposition (I'm sorry to bother you...; I know you're busy, but...). A face-saving act that emphasizes a person's positive face will show solidarity and draw attention to a common goal (Let's do this together...; you and I have the same problem, so...).

\section{TOEFL proficiency test}

Testing is a universal feature of social life" McNamara (2010). In general, the test has many purposes and design, the purposes, and its design will affect the name of test i.e. drug test, DNA test, paternity test, lie detection tests. The example which is DNA test has a purpose to identify the DNA pattern and the structure. Therefore, basically with the term of language test, the test is purposely designed to elicit the language

CELTIC: A Journal of Culture, English Language Teaching, Literature \& Linguistics

PISSN 2356-0401 EISSN 2621-9158

VOLUME 5 NO 22018 
ability from language learner. TOEFL or was officially published in 1964 and then it has become one trustworthy English proficiency test. At the first time, the TOEFL test type was known as PBT (Paper Based Test). However, due to the progression of time and technology the type changed into TOEFL CBT (Computer Based Test) and then latest type TOEFL IBT (Internet Based Test). On their website states TOEFL test measures the non-native English speaker in how they use or understand the language, as they spoke, heard, written, and read. The TOEFL test is the most widely respected English-language test in the world, recognized by more than 10,000 colleges, universities and agencies in more than 130 countries, including Australia, Canada, the U.K., and the United States

\section{Method}

The researcher analyzed on test items from TOEFL on listening section in which the researcher tried to analyze the semantic and pragmatic content. . Each ofthe items will be described fully to see whether it is a semantic or pragmatic question based. By following to the condition the researcher chose a qualitative research approach for this research. The statement is supported by Ary. et. al (2010) Qualitative researchers are looking forward to understanding the phenomenon by focusing on the total picture rather than breaking it down into variables. The goal of qualitative is a holistic picture and depth of understanding rather than a numeric analysis of data.

Due to the original TOEF test cannot be obtained unless from the authority here the research analyzed TOEFL simulation book with the title TOP NO 1 TOEFL SIMULATION published by FORUM TENTOR INDONESIA in 2015. The book consists of several lesson, tricks, guide, and exercise to help students or test taker solving TOEFL easily, the book also included CD for Audio Listening section. This book provides a compilation of test items from PBT/IBT/CBT++AcEPT which are given in the Try Out Exercise that has 3 sections; Listening, Structure and Written Expression, and Reading but the researcher will focus only the on the Listening section.

\section{Procedure}

First the researcher is collecting the TOP No 1 TOEFL simulation book which was on sale in the bookstore, due to the original TOEFL test were not accessible by the nonauthority, here the researcher will use the Try Out TOEFL book. This book is suitable for this research too because it has an audio test provided that match the research objective. Then, the researcher selects several test items on the Listening part. This book has two parts of Try Out in which every part has one Listening section. Furthermore the procedure continue on accumulating all test items from each Try-Out sections, therefore the total number is 30 questions to be analyzed.

The data that were collected will be then analyzed. In analyzing the data, the researcher described in three stages as follows:

a. Creating table

In this stage, the researcher creates a table to put the data and matching which test items that suit the Pragmatic and Semantic theory concept from Yule (2010) Study of Language book. The table can be seen as follows:

CELTIC: A Journal of Culture, English Language Teaching, Literature \& Linguistics

PISSN 2356-0401 EISSN 2621-9158

VOLUME 5 NO 22018 
Table 1. Table analysis of Semantic and Pragmatic context

\begin{tabular}{|l|l|l|l|l|}
\hline No & \multicolumn{1}{|c|}{ Question } & $\begin{array}{c}\text { Type of } \\
\text { Pragmatic } \\
\text { Context }\end{array}$ & $\begin{array}{c}\text { Type of } \\
\text { Semantic } \\
\text { Context }\end{array}$ & \multicolumn{2}{|c|}{ Note } \\
\hline 1 & $\begin{array}{l}\text { Example question } \\
\text { from section A } \\
\text { type ... }\end{array}$ & $\begin{array}{l}\text { Pragmatic } \\
\text { the narrator uses } \\
\text { politeness in the } \\
\text { conversation }\end{array}$ \\
\hline 2 & $\begin{array}{l}\text { Example question } \\
\text { from section B }\end{array}$ & $\begin{array}{l}\text { Semantic } \\
\text { type.... }\end{array}$ & $\begin{array}{l}\text { The question is } \\
\text { referring the job from } \\
\text { speaker A }\end{array}$ \\
\hline
\end{tabular}

b. Coding and Reducing

Coding and reducing are the other ways to analyze the data. In the process of coding and reducing, the researcher had some steps, Firstly, the researcher breaks down the data which question is pragmatic, semantic or none of them. After that, the researcher identified which test item has the answer that is fit the research objective.

c. Interpreting and Representing

In this step, the researcher interpreted the classified data by narrative description and interpretation. The researcher will also take the result to make it convenient to the expert.

\section{Findings}

\section{Semantic Context Found on Listening Section in TOEFL Try Out Simulation.}

Among 30 questions that were analyzed, the researcher found several contexts of semantic in the Listening section of Try Out TOEFL simulation. Those contexts are Meaning, Semantic Feature, and Semantic Roles. Furthermore, the occurrences of the semantic type in the Listening section is described as follows:

Table 2. Types of Semantic Context found on Listening Section

\begin{tabular}{|l|l|l|c|}
\hline $\begin{array}{c}\text { Types of Semantic } \\
\text { Context }\end{array}$ & $\begin{array}{l}\text { Appendix I (Try } \\
\text { Out 1) }\end{array}$ & $\begin{array}{l}\text { Appendix II (Try } \\
\text { Out 2) }\end{array}$ & Total \\
\hline Meaning & $\begin{array}{l}\text { Found in question } \\
\text { number 4 and 5 }\end{array}$ & - & 2 \\
\hline Semantic Feature & $\begin{array}{l}\text { Found in question } \\
\text { number 1 }\end{array}$ & $\begin{array}{l}\text { Found in question } \\
\text { number 2 }\end{array}$ & 2 \\
\hline Semantic Roles & $\begin{array}{l}\text { Found in question } \\
\text { number 13 }\end{array}$ & $\begin{array}{l}\text { Found in question } \\
\text { number 1, 2,9 }\end{array}$ & 4 \\
\hline
\end{tabular}

Based on the table above from 30 test items analyzed on both Appendix I and II, Semantic Context found were 8 in total. In the Appendix I (Try Out 1), 4 test items were categorized as semantic type. The following type that were spotted namely; Meaning (in

CELTIC: A Journal of Culture, English Language Teaching, Literature \& Linguistics 
question number 4 and 5 in Appendix 1), Semantic Feature (in question number 1 on Appendix I and question number 2 in Appendix II), and Semantic Roles (in question number 13 in Appendix I and in question number 1, 2, and 9 in Appendix II). The type of semantic context that mostly occurred is Semantic Roles (4 questions), followed by Semantic Feature (2 questions) and Meaning (2 questions).

\section{Meaning Found on Listening Section in TOEFL Try Out Simulation}

The next type of semantic context found is Meaning which occurred in question number 12 and 15 in the Appendix I. Those test items can be categorized to be a Meaning because they showed a conceptual meaning in which leads into a new concept or ideas to the audience. In the example question number 12, the woman on the passage asked 'why do polar bears have thick fur?' Then the man narration was answering that by said 'Because they live in cold place' (See Appendix I, second page). The phrase of the man is a response to the idea that the purpose of thick fur on the polar bear is because due to their habitat on a cold place, indirectly tells to general ideas that some animal in cold place has fur to keep them warm without giving that statement on the passage. This type of question will generate the audience to comprehend the whole passage. The answers option for number 12 also giving a hint to the meaning of the question passage. In option A (See Appendix I, page 2), which is the correct answer, it connects to ideas that the whole narration is talking about the fur on polar bear as protection from the cold.

\section{Semantic Feature Found on Listening Section in TOEFL Try Out Simulation}

Semantic Feature occurred in question number 3 in Appendix I and number 8 in Appendix II. The reason behind those test items is categorized as Semantic Feature because it has an unfamiliar wording. The bolded sentence as in number 3 in Appendix I 'Would you give me a hand?' (See Appendix I, first page) containing a meaning in which the sentence is grammatically correct but the meaning is 'odd' or semantically (meaning) weird. Semantic Feature is a type that tends to explain the oddness of semantic. Therefore, we cannot directly jump into the meaning of the bolded sentence. The direct meaning of 'gives me a hand' is a phrase that is not as someone would give the limb of their body part rather than it is a different call for help. This condition is being explained in Semantic Feature where certain words or sentence cannot be interpreted directly and supposed to be looked with the correct context behind it.

\section{Semantic Roles Found on Listening Section in TOEFL Try Out Simulation}

Semantic Roles is the third type of semantic context found in the Try Out. Based on table 4.1 "Types of Semantic Context found on Listening Section", this type occurred in question number 13 in Appendix I and question number 4, 8, 36 in Appendix II. The justification of how the test items are categorized as semantic roles is due to their sentence structure. Semantic roles enroll in the explanation of Agent and Theme. An agent is a subject or object that affecting a noun. For the example, question number 4 in Appendix II of the bolded sentence it displayed a sentence structure that consists of a subject, verb, and the noun. However, the semantic roles context explains the structure 
by differing which one is Agent or Theme looking on the sentence meaning. 'He usually drives a car...'. On the passage (See Appendix II, Page 1) is a sentence of which the Agent is the 'He' as an agent that moved the 'Car' which become the theme.

\section{Pragmatic Context Found on Listening Section in TOEFL Simulation}

From the 30 questions the researcher analyzed on both Appendixes, Try Out 1 and Try Out 2 , the pragmatic context was found in their several types. Those are Context, Reference, Speech Act Roles, and Politeness. Furthermore, the occurrences of the pragmatic type in the Listening section is described as follows:

\begin{tabular}{|l|l|l|c|}
\hline $\begin{array}{c}\text { Types of Pragmatic } \\
\text { Context }\end{array}$ & $\begin{array}{l}\text { Appendix I / Try } \\
\text { Out } 1\end{array}$ & $\begin{array}{l}\text { Appendix II / Try } \\
\text { Out 2 }\end{array}$ & Total \\
\hline Context & 6 and 10 & $3,6,7,10,14$ & 7 \\
\hline Politeness & $2,7,9$ & 4 & 4 \\
\hline Reference & $\begin{array}{l}2,3,4,5,6,7,8,9, \\
10,11,12,14,15\end{array}$ & $\begin{array}{l}11,12,7,7,8,9,14,15 . \\
11,12,15\end{array}$ & 25 \\
\hline Speech Act & 3 and 15 & 9 and 10 & 4 \\
\hline
\end{tabular}

Table 3. Types of Pragmatic Context found on Listening Section.

Based on the table above, among 30 test items on the Listening section of TOEFL Try Out there are 40 pragmatic contexts were found. The number of pragmatic contexts is much more than the analyzed test because one question can have more than one pragmatic types. The several type of pragmatic which were found namely; Context (found in question number 6 and 10 in Appendix I and question number 3,6,7,10,14 in Appendix II), Politeness (found in question number 2, 7, 9 in Appendix I and in question number 4 in Appendix II), Reference (found in question number 2, 3, 4, 5, 6, 7, $8,9,10,11,12,14,15$ in Appendix I and in question number 1, 3, 6, 7, 8, 9, 10, 11, 12, 13, 14, 15 in Appendix II), and Speech Act (found in question number 3 and 15 in Appendix I and question number 9 and 10 in Appendix II). The type of pragmatic context which is mostly occurred is Reference ( 25 questions), followed by Context ( 7 questions), and in the third place is Speech Act (7 questions) and Politeness (7 questions).

\section{Context Found on Listening Section in TOEFL Try Out Simulation}

The context type is one of the pragmatic contexts found in the Listening section of TOEFL Try Out. The type was spotted in question number 6 and 10 on Appendix I and in question number 3, 6, 7, 10, 14 on Appendix II. The context enrolls with the use of the word, it means some words will have more than one used in creating meaning. In question number 7 in Appendix II (see Appendix II, page 3) on the first narration of the woman, she said "It sounds nice. Snails with garlic." The term of snails and garlic on that passage is not the meaning of a regular object as the snail is the animal and garlic is

CELTIC: A Journal of Culture, English Language Teaching, Literature \& Linguistics 
a vegetable, yet it is a meal that served in a restaurant if we pay attention to the context of place settings. Moreover, the next statement on the passage helps the audience to understand the main idea by stating the narrator favorite food.

\section{Politeness Found on Listening Section in TOEFL Try Out Simulation}

Politeness occurs in question number 2, 7, 9 of Appendix I and in question number 4 of Appendix II. Those test items can be categorized as the politeness due to the consistency of modest and nice speech delivery. In question number 4 on Appendix II, it was stated on the bolded sentence when the woman was saying 'Ohh... I don't think so' (see Appendix II, page 2), she was rejecting to the man statement but the voice tone and the way she was saying it in the audio seems very soft and in low pitch. Another example of politeness in question number 7 on Appendix I, when the man said a negative response after an argument by the woman, he said 'I don't think so. There are only three steps like trapping the sun's energy..." (See Appendix I, page 3). The way the man was stating also in very genuine tone on the voice record and he corrected the wrong argument the woman said on the previous passage

\section{Reference Found on Listening Section in TOEFL Try Out Simulation}

The reference type is the most context found on the Try Out. This type explains the 'referencing back' which is the common questions type of the listening section. For the example, the question number 2, 3, and 4 on Appendix I (see Appendix I, page 1) mostly the question is based on what we have heard on the narration, then the narrator will ask of certain passage main idea or the whole conversation meaning. In the passage number 3, a man in the passage said 'Welcome, anything I can do for you?', and then the woman said 'I want to buy some historical books' in replying the man question. Soon after all the passage is delivered, the narrator asked 'what does probably the man do?' This kinds of question are refereeing back to the passage and causing the audience to remember what they already listened, only by focusing on the passage they can have their answer but also they need to listen to all the passage narration in order to understand the passage meaning. The woman narration helps the audience to understand the 'man' job and then it leads to the answer that the man is working in there and will help the woman to have her book.

\section{Speech Act Found on Listening Section in TOEFL Try Out Simulation}

Based on table 4.2 'Types of Pragmatic Context on Listening Section', speech act occurred in question number 3 and 15 on Appendix I and in question number 9 and 10 on Appendix II. Speech act is explaining about "requesting", "commending", "questioning", or "informing" in which it suits in almost every question on Try Out because every question is using an interrogative sentence. The researcher only selected some speech act which found on the passage of conversation and some narrator questions to see the speech act. In question number 9 on Appendix II (see Appendix II, page 3) the speech act is spotted on the man narrator, he said 'How was the movie last night?', that statement showed a speech act due to the man were using "questioning" in the conversation

\section{DISCUSSION}

The discussion elaborates the finding of the research and also relating to the expert theories which is helping to justify the research problem 'What are the semantic context found in the listening section of the TOEFL Try Out simulation?' and 'What are the pragmatic context found in the listening section of the TOEFL Try Out simulation?' In here the researcher determined to identify the semantic and pragmatic context in the Listening section which consisted of two

CELTIC: A Journal of Culture, English Language Teaching, Literature \& Linguistics

PISSN 2356-0401 EISSN 2621-9158

VOLUME 5 NO 22018 
parts. The research sees that semantic and pragmatic do exist in the proficiency test. Trudgil (2000) states sociolinguistics aspects affect the language user in every context. In the proficiency test such as TOEFL, the listening section create the passage in which the narration is quite familiar. This due to the criteria of a good test should have an authentic test based (McNamara, 2010). The purpose of the test is to measure how far the proficiency of an English speaker. Therefore the common conversations in life and society are included to check whether they will understand a conversation in English settings. On the previous research done by Karbalei\&Rahmanzade (2015) and Garacia (2004), both of the research were analyzed the Semantic and Pragmatic which justified that semantic and pragmatic contained in the proficiency test.

The researcher used Yule (2010) book 'Study of Language' as the guideline to determine whether a sentence is categorized as Semantic or Pragmatic. Yule (2010) definition is also used in the Karbalei\&Rahmanzade (2015) and Garacia (2004). The researcher analyzed the test item by looking into the transcribe of the Listening Try Out and then comparing to Yule (2010) Semantic and Pragmatic classification. Based on the finding, the researcher found the Semantic and Pragmatic have a different amount of quantity in the Try Out on both Listening section. Semantic has less number than Pragmatic. This happened due to the type of Pragmatic context type; Reference is seen in almost every test items. The narrator on the question is 'referring back' (which is the characteristic of Reference) to the passage in which the questions are asking the meaning or the main idea.

On the other hand, the semantic context in the table was spotted in every first or second question. The beginning questions are mostly focused on a single word or simple passage where the semantic always took part due to the concept that focused on meaning in semantic. The pragmatic is occurring in almost every question and mostly spotted in every longer conversation. In the TOEFL, there are several questions that applied one mid-long conversation to answer 2 or 3 questions. On those questions, mostly pragmatic are used in order to create a question that is asking what is the passage talk about. Again, in here Referencing is being spotted.

As a further matter, Semantic and Pragmatic is creating little difficulties in doing the Try Out. There are some meanings that need to be deeply analyzed or even should be familiar with the word (i.e. the used of Idiom or Figurative Meaning in the passage). Therefore, Jong (2002) stated to fully understand pragmatic or semantic, it requires a full understanding of their characters to gain the knowledge of those aspects. However, this research also has its drawback due to the lack of real "data" that was taken. In this research, the data that were taken is a document instead of a real subject. The object is a test item that the maker whom creating the test are not involved in the analyzing process. Pragmatic or Semantic is a condition that should be analyzed by asking it directly to the people who used it so we cannot just assume it, therefore we can understand it very well. Van Dijk (1977) states it needs contextual information, interlocutor role play statues, the physical setting of the conversation, and types of context that probably has the occurrence of the communicative act to comprehend a pragmatic meaning. Therefore, many interlocutors seem to feel hardship in responding to pragmatic and making people tend to the investigation, assume, and expecting. In this case, the researcher could have misinterpreted the pragmatic or even semantic if the real meaning delivered by the test maker is different than it thought. However, the

CELTIC: A Journal of Culture, English Language Teaching, Literature \& Linguistics

PISSN 2356-0401 EISSN 2621-9158

VOLUME 5 NO 22018 
researcher can claim the research is valid because the explanation of semantic and pragmatic itself can be identified due to the multiple choice answers on the Try Out. It helps the researcher to identify by seeing the correlation of the narration passage and the correct answer.

\section{CONCLUSION}

The Semantic Context exists in the TOEFL Try Out on the Listening Section. The total of semantic context found is 8 questions among the 30 questions analyzed. The type of semantic context which is found is; Meaning, Semantic Feature, and Semantic Roles. The type of semantic context which is mostly occurred is Semantic Roles (4 Questions), then followed by Semantic Feature (2 Questions) and Meaning (2 Questions).On the other hand, the Pragmatic context quantities are found more than the semantic context. From the 30 analyzed questions, the Pragmatic context found are 40 questions, it happens because one question can have more than Pragmatic Context. The Type of Pragmatic context found on test items in the Listening Try Out are; Context, Politeness, Reference, and Speech Act. The type of pragmatic context which is mostly occurred is Reference ( 25 questions), followed by Context ( 7 questions), and in the third place is Speech Act (7 questions) and Politeness (7 questions).

\section{Reference}

Allami, H. (2014). Pragmatic Knowledge Assessment in Listening Sections of IELTS Tests. Iran: Yazd University

Ary, D. Jacobs, L. C., Sorensen, C., \&Razavieh, A. (2010). Introduction to Research in Education Eighth Edition. Belmont: Wadsworth

BARDOVI-HARLIG, K. (2011). Do Language Learners Recognize Pragmatic Violations Pragmatic Versus Grammatical Awareness in Instructed L2 Learning?

Bowen, G. A. (2009) Document Analysis as a Qualitative Research Method. Qualitative Research Journal, Vol 9, No 2, 27-40. Cullowhee: Western Carolina University

British Council IELTS - Home Retrieved from http://indonesia.ielts.britishcouncil.org/iorpsea/html/registration/selectExamTyp eServlet.do?gclid=Cj0KCQjwr4beBRDNARIsAGZaZ5cKdZZiDoc2SOroYNoikYeH41XV8CxbxcSH7F7LBnUj7HfoTDBscaApNqEALw_wcB

Creswell J. W. (2012) Educational Research: Planning, Conducting, and Evaluating Quantitative and Qualitative Research fourth edition. Boston: Pearson.

Fraenkel, Jack. R., and Norman E. Wallen. 2012. How to Design and EvaluateResearch in Education 8th Edition. Boston: McGraw-Hill Higher Education.

Garcia, P. (2004). Pragmatic Comprehension of High and Low Level Language Learners. Arizona: Northern Arizona University

IELTS for Scholarship by British Council. (2018). Retrieved from https://www.britishcouncil.org/

IELTS test taker demography. (2017) Retrieved from https://www.ielts.org/teachingand-research/test-statistics

CELTIC: A Journal of Culture, English Language Teaching, Literature \& Linguistics

PISSN 2356-0401 EISSN 2621-9158

VOLUME 5 NO 22018 
Jianda, L. (2006). Assessing EFL learners' interlanguagepragmatic knowledge:Implications for testers and teachers. China: Guangdong University of Foreign Studies

Jung, Y.J. (2002). Issues in Acquisitional Pragmatics. New York: Columbia University

Karbalaei, A. \&Rahmanzade, M. K. (2015). An Investigation into Pragmatic Knowledge in the Reading Section of TOLIMO, TOEFL, and IELTS Examinations. Tehran: Farhangian University

Kasper, G., \& Schmidt, R.G. (2008). Developmental Issues in Interlanguage Pragmatics.

Katz, J. J. (1972). Semantic theory (Studies in language). USA: Harper \& Row

Katz, J. J \& Fodor, J. A. (1963). The Structure of a Semantic Theory, Vol. 39, No. 2. (Apr. - Jun., 1963), pp. 170-210. Massachusetts: Massachusetts Institute of Technology.

Latief, M. A. (2016) Research Methods on Language Learning an Introduction. Malang: UniversitasNegerei Malang (UM Press)

Leech, G. N. (1983). The principles of pragmatics. New York: Longman.

McNamara, T. (2000) Language Testing. Oxford: Oxford University Press

Sheppard, B. (2013). Teaching and Researching Listening ( $2^{\text {nd }}$ ed.). USA: University of Oregon

Soler, E.A \&Martínez-Flor, A. (2008). Investigating Pragmatics in Foreign LanguageLearning, Teaching and Testing. UK: Cromwell Press Ltd

Tan, P. (1994). Key concepts in ELT. ELT Journal, 48(1), 100

TOEFL test taker demography and Types of TOEFL test. (2017). Retrieved from https://www.ets.org/toefl

Trudgill, P. (2000). Sociolinguistics: An introduction to language and society fourth edition. London: Penguin.

Van Dijk, T. (1977). Text and Context. London: Longman

Vitásková, K. \&Šebková, L. (2017). The Variable Professional Perception in Assessment of PragmaticLanguage Level in Autism Spectrum Disorders and RelatedDevelopmental Difficulties. Czech Republic: Palacký University in Olomouc

Yule, G. (2010). The study of language $4^{\text {th }}$ edition. Cambridge, UK: Cambridge University Press 